\title{
DEFINISI KEMBALI BUSINESS PROCESS PENJUALAN RITEL AKIBAT PENGARUH TEKNOLOGI INFORMASI
}

\author{
Andi Fuji Rahman \\ PT IPSOS Market Research \\ Mega Plaza 6th floor jl.HR Rasuna Said Kav. C3, RT.3/RW.1, Karet, Jakarta 12920 \\ Andi.Rahman@ipsos.com
}

\begin{abstract}
Living within internet become easier, back to 90 or earlier when need something we have to go shop to buy something we needed. But now these days, we just picked the phone make a phone call to shop and make an order. Just couple hours the product we are needed just arrived right front our house, pick the product and pay the cash. Everything become very simple. Internet era make us to redefinition of Business Process of sales. Back to earlier, the buyer and the sales have to meet make transaction. But they don't have to meet again, and the matter fact, they don't know to each other completely. Now the transaction support by internet and bank, they make this impossible. Internet make people (buyer and sales) meet in web world, the make transaction. And finally the buyer pay the price via bank and again the buyer pay the price via internet through the bank. And the sales after received confirmation from the bank, they right the way to pack the package and delivery the package from courier service. Data of year 2013-2013 average increment of direct sales only grows amount 9.9\% and increment of sales online grows up to 59.9. it seem increment of sales of online very massive in period year 2013 up to 2017, and the number sales of online almost half of direct sales i.e. $2019 \mathrm{~T}$ and sales of online i.e $108 \mathrm{~T}$. With regression coefficient formula look relationship direct sales with increment of Indonesia's growth economy i.e. $0.212 \%$ and sales online growth i.e. $0.223 \%$, it means both sales online and direct sales have one direction refer to Indonesia's economy growth, only sales online has stronger relationship i.e. $0.223 \%$ and gap $0.011 \%$ compare to direct sales.
\end{abstract}

Keyword: sales online, direct sales, Indonesia's economy growth

\section{PENDAHULUAN}

\subsection{Internet}

Bicara mengenai internet saat ini hampir semua orang telah mengetahui tentang internet. Bahkan untuk anak-anak usia dini sudah paham mengenai internet dan memasuki dunia maya tersebut dengan peralatan yang mereka miliki.

Bisa dikatakan sekarang dalam masyarakat modern saat ini sangat memahamami dengan internet dan memiliki ketergantungan yang cukup tinggi. 
Dengan adanya internet, mereka memiliki kemudahan-kemudahan yang didapat. Bukan hanya untuk berbelanja dalam dunia maya tetapi juga dijadikan tempat bagi para pengusaha mendapatkan uang dengan menjualkan aneka ragam produk mereka dalam dunia maya.

Berikut ini adalah sejarah internet yang dijelaskan ke dalam beberapa fase sebagai berikut:

1. Pada tahun 1960-an, internet digunakan pada dunia militer melalui advanced research project agency yang disingkat dengan ARPA merintis sebuah sistem jaringan ARPANET. Arpanet merupakan cikal bakal terbentuknya internet.

2. Pada tahun 1980 -an, internet mulai digunakan secara terbatas pada dunia akademisi.

3. Protokol standar TCP/IP mulai dipublikasikan ke umum pada tahun 1982.

4. Sistem nama domain mulai digunakan pada tahun 1984.

5. National Science Foundation Network (NSFNET) dibangun pada tahun 1986 dan mulai menggantikan peran ARPANET sebagai jaringan riset. Beberapa jaringan internasional di berbagai negara mulai dibangun dan dihubungkan dengan NSFNET.

6. AFPAENT dibubarkan pada tahun 1990. Akan tetapi internet tetapi internet tetap terus berkembang sampai sekarang.

7. Awalnya informasi yang bias didapatkan lewat internet hanyalah informasi berbagai teks. Pada tahun 1990, layanan berbasis tampilan grafis yang www (world wide web) mulai dikembangkan oleh CERN.

8. Pada tahun 1993, interNIC didirikan untuk melayani pendaftaran nama domain.

9. Sekitar tahun 1994, internet mulai digunakan di Indonesia.

Pada era sekarang era internet makin mudah dijangkau, selain karena perkembangan internet itu sendiri, tetapi juga adalah perkembangan peralatan yang digunakan oleh pengguna. Bila pada era tahun 1990-an untuk mengakses internet hampir $100 \%$ melakukan dengan menggunakan komputer PC dan tambahan peralatan seperangkat modem. Pada zaman sekarang berkembang dari penggunaan PC, menjadi penggunaan laptop hingga saat ini dengan menggunakan peralatan handphone pintar (smartphone), yang membuat akses internet semakin mudah dan dapat diakses dimana pun kita berada.

Kemudahan penggunaan internet, memudahkan kita dalam melakukan aktivitas sehari-hari, dari kegiatan sosial bahkan kegiatan perdagangan seperti pembelian barang-barang yang kita sukai. Pada tahun era 1990-an kegiatan jual beli sering kita lakukan dengan melakukan kunjungan ke tempat-tempat dimana produk tersebut perjualbelikan. Namun sekarang kegiatan tersebut dapat kita lakukan dengan mudah melakukan pembelian dari dunia maya dengan mengakses beberapa situs perdagangan yang terkenal seperti bukalapak, lazzada Indonesia, FJB Kaskus, tokopedia, Bhinneka, Blibli, mataharimall dan lain-lain. 


\subsection{Bukalapak}

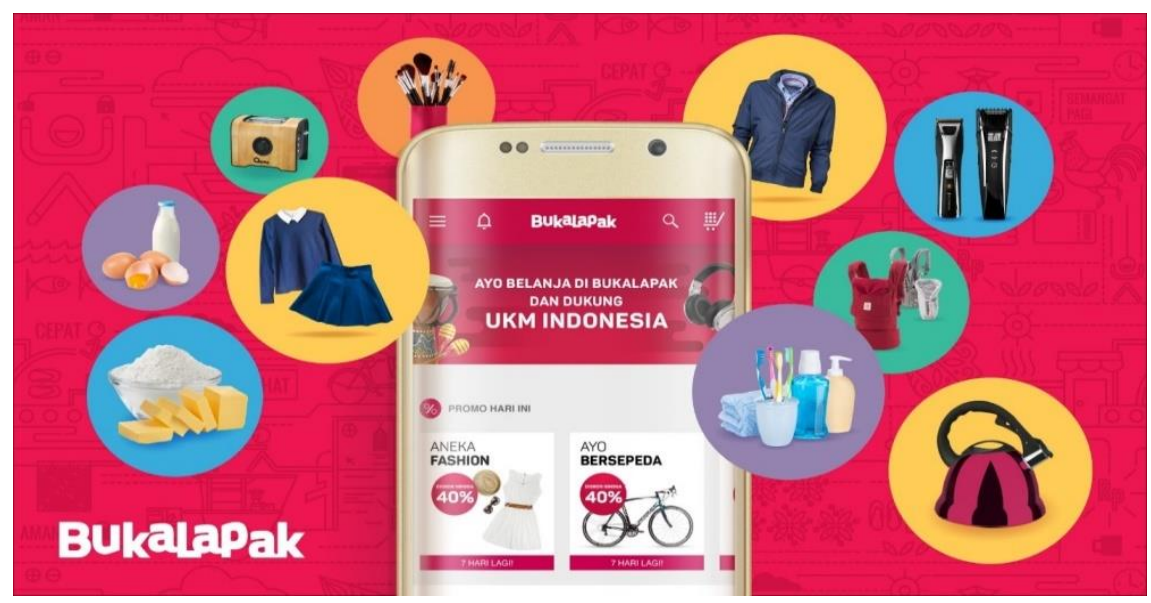

Gambar 1. Halaman depan bukalapak

Bukalapak merupakan salah satu pasar online (online marketplace) terkemuka di Indonesia (biasa dikenal juga dengan jaringan toko online) yang dimiliki dan dijalankan oleh PT Bukalapak. Seperti halnya situs layanan jual beli online dengan model bisnis consumer to consumer (C2C), Bukalapak menyediakan sarana penjualan dari konsumen ke konsumen di mana pun. Siapa pun bisa membuka toko online untuk kemudian melayani calon pembeli dari seluruh Indonesia baik satuan atau pun dalam jumlah banyak. Pengguna perorangan atau pun perusahaan dapat membeli dan menjual produk, baik baru maupun bekas seperti sepeda, ponsel, perlengkapan bayi, gadget, aksesoris gadget, komputer, tablet, perlengkapan rumah tangga, busana elektronik dan lain-lain.

\subsection{Lazada Indonesia}

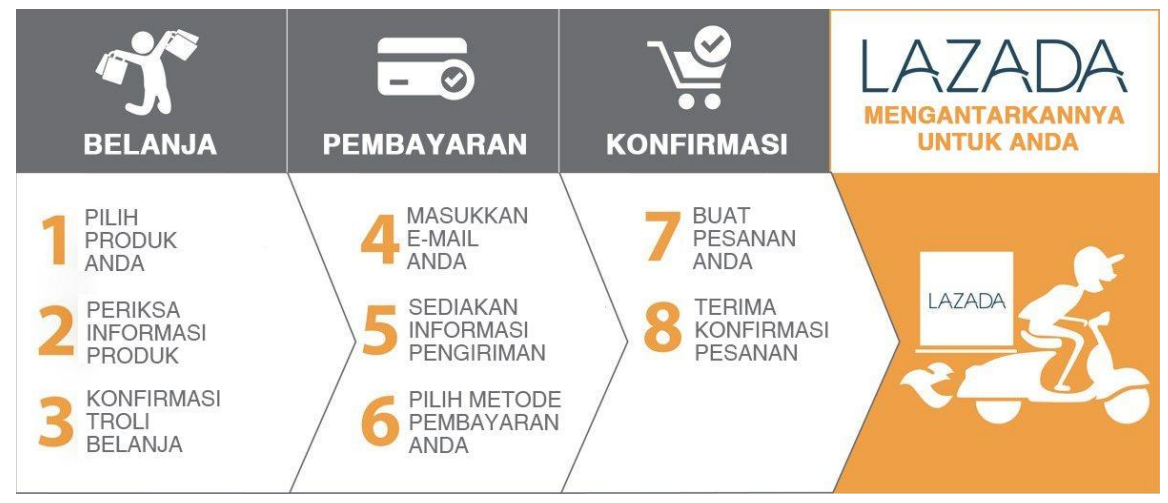

Gambar 2. Halaman depan Lazada

Lazada Indonesia adalah pusat belanja online yang menawarkan berbagai macam jenis produk mulai dari elektronik, buku, mainan anak dan perlengkapan bayi, alat kesehatan dan produk kecantikan, peralatan rumah tangga, dan perlengkapan traveling dan olah raga. Lazada Indonesia didirikan pada tahun 2012 dan merupakan salah satu cabang dari jaringan retail online lazzada di Asia 
Tenggara. Group Lazada international di asia tenggara terdiri dari lazzada Indonesia, lazzada Malaysia, Lazada Vietnam, lazzada Thailand, Lazada Filipina. Jaringan lazzada asia, asia tenggara merupakan cabang anak perusahaan jaringan perusahaan internet Jerman rocket internet. Rocket internet merupakan perusahaan online incubator yang sukses menciptakan perusahaan-perusahaan online inovatif di berbagai belahan dunia. Berkantor pusat di Berlin, Jerman, proyek yang dimiliki Rocket internet antara lain zalando, toptarif, eDarling.

\subsection{Permasalahan}

Dengan banyaknya penjualan secara online, membuat banyak konsumen beralih dari pembelian secara langsung dengan mendatangi toko-toko atau gerai tempat mereka menjual produk, ke pembelian secara online. Berikut ini adalah beberapa alasan penjual secara langsung menurun bila dibandingkan dengan penjualan secara online:

- Data dari Asosiasi Peritel Indonesia (Aprindo) pada paruh waktu tahun 2017 terjadi penurunan pembelian sebesar US\$ 4.89 juta, atau $1.4 \%$ dari total kapitalisasi ritel offline yang sebesar US\$320 miliar. Artinya porsi traksaksi offline masih sangat besar dibandingkan ritel online. Namun diakui penjualan ritel mengalami penurunan dibandingkan 4-5 tahun lalu, salah satu penyebabnya sekarang adalah para konsumen lebih suka melakukan traveling, mengeksplor tempat-tempat wisata baik dalam negeri maupun luar negeri.

- Perubahan prioritas para millennial ini mau tidak mau ikut andil terhadap kelesuan ritel di Tanah Air. Selain mengubah pola konsumsi dari sekedar belanja barang-barang ritel, mereka juga sudah memiliki skala prioritas dalam hidup.

Kesadaran akan investasi sudah mulai merambah kehidupan para millennial dewasa ini. Mereka sadar pentingnya investasi. Menempatkan dananya di instrumen investasi seperti tabungan, deposito dan lainnya.

Ini bisa dilihat dari data Bank Indonesia (BI) bahwa dana pihak ketiga (DPK) di 6 bulan pertama tahun ini naik 2,3\%. Artinya, cukup banyak mereka yang menempatkan dananya di deposito berjangka.

- Meski bukan menjadi penyebab utama, pelemahan daya beli masyarakat juga turut andil terhadap lesunya sektor ritel Tanah Air. Sebab jumlah kelas menengah-bawah (mereka yang pendapatannya pas-pasan hingga rentan miskin dan yang miskin) sangat banyak mencapai sekitar 170-an juta orang, dari total penduduk 261 juta pada statistik 2016.

Data Badan Pusat Statistik (BPS) pun mencatatkan penduduk miskin per Maret 2017 sekitar 27,7 juta jiwa. Sedangkan orang yang berada di garis atau di bawah garis kemiskinan itu hampir $70 \%$ pendapatannya untuk konsumsi makanan. 
BPS mengakui ada perlambatan daya beli masyarakat. Ini tercermin dari konsumsi masyarakat (terdiri dari belanja barang, sandang, pangan, dan papan/rumah), yang biasanya mampu tumbuh di atas 5\%, di kuartal ketiga tahun 2017 hanya mampu tumbuh di sekitar 4,9\%.

- Perekonomian domestik dalam 5 tahun terakhir mengalami perlambatan seiring berakhirnya era komoditas, yang merupakan dampak dari pelemahan ekonomi global. Sehingga menjatuhkan harga-harga komoditas dunia seperti kelapa sawit, batubara, dan lainnya, yang merupakan ekspor utama Indonesia.

Ini bermula dari meluasnya krisis finansial yang berasal dari skandal subprimemortgage (KPR Subprima), yaitu pembiayaan kredit perumahaan warga AS, yang membuat salah satu bank terbesar di Perancis, BNP Paribas, membekukan beberapa sekuritas yang terkait, karena pembiayaan KPR ini dinilai berisiko tinggi.

Subprimemortgage adalah pembiayaan kredit kepemilikan rumah untuk masyarakat AS yang non bankable atau kurang memiliki kemampuan finansial yang memadahi.

Akibat itu, gejolak pasar finansial menyebar ke seluruh dunia dan semakin membesar seiring bangkrutnya Lehman Brothers (bank investasi terbesar AS). Diikuti krisis keuangan di negara-negara maju seperti Eropa dan Jepang.

Akhirnya, krisis keuangan dunia pun pecah di kala itu dan berimbas ke perekonomian Indonesia, yang tercermin dari anjloknya IHSG (Indeks Harga Saham Gabungan) hampir separuhnya, dari 2.627,3 ke 1.355,4 pada penutupan di Desember 2008. Nilai tukar rupiah berangsur-angsur tergerus dari sebelumnya di Rp. 8000-an per dolar AS menjadi sekitar Rp13.000-an

- Faktor lain dari penutupan gerai ritel ini juga diakui para pelaku usaha sebagai bentuk mengikuti perkembangan zaman. Perubahan cara belanja pun tidak dipandang sebelah mata. Perkembangan teknologi informasi telah mendorong peritel online dan mengubah gaya hidup orang dalam berbelanja.

Diakui hingga saat ini belanja online belum menggeser carabelanja offline. Ini merujuk pada proporsi ritel yang masih $1,4 \%$ dari kapitalisasi ritel offline tadi. Artinya, barang-barang ritel yang dibeli secara online tidak ada separuhnya dibanding secara offline.

Akan tetapi, peritel pun tidak mengesampingkan potensi ritel online ini ke depannya. Perubahan gaya berbelanja konsumen memaksa pengusaha ritel konvensional untuk mengubah strategi pemasaran, sekaligus efisiensi operasional. 
Tidak hanya di Indonesia, lesunya penjualan ritel dan berbuntut pada penutupan toserba dan gerai ritel lainnya tampaknya juga menjadi fenomena global. Perlambatan ekonomi dunia telah membuat warga mulai mengurangi pengeluaran perabot, pakaian, dan makanan di berbagai negara seperti Australia, Singapura, Amerika Serikat, Inggris, Malaysia, dan masih banyak lagi.

Berikut Gerai Department Store dan gerai ritel lainnya di Indonesia dan luar negeri yang mulai ditutup satu per satu:

\section{Matahari Departemen Store}

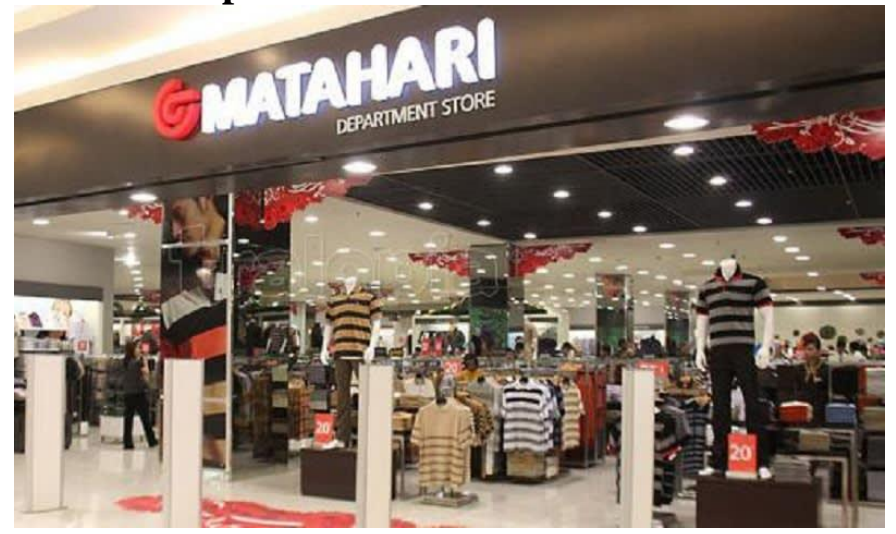

Gambar 3: Gerai Matahari Departemen Store

Siapa yang tak kenal toko serba ada satu ini. Departement Store yang merupakan bagian dari Lippo Group ini sudah lebih dulu bertransformasi ke perdagangan online (e-commerce) yakni MatahariMall.com. Di tengah perlambatan industri ritel selama ini, mereka menutup 2 gerai di Pasaraya Blok M dan Manggarai.

Terbaru, mereka mengumumkan akan menutup gerai Matahari Department Store yang ada di Mall Taman Anggrek pada akhir tahun ini. Penutupan gerai oleh PT Matahari Department Store Tbk ini disinyalir salah satunya lesunya penjualan ritelnya. Tak tanggung-tanggung, kinerja keuangannya dikabarkan menyusut seperempat lebih dari omset sebelumnya.

\section{Ramayana Departemen Store}




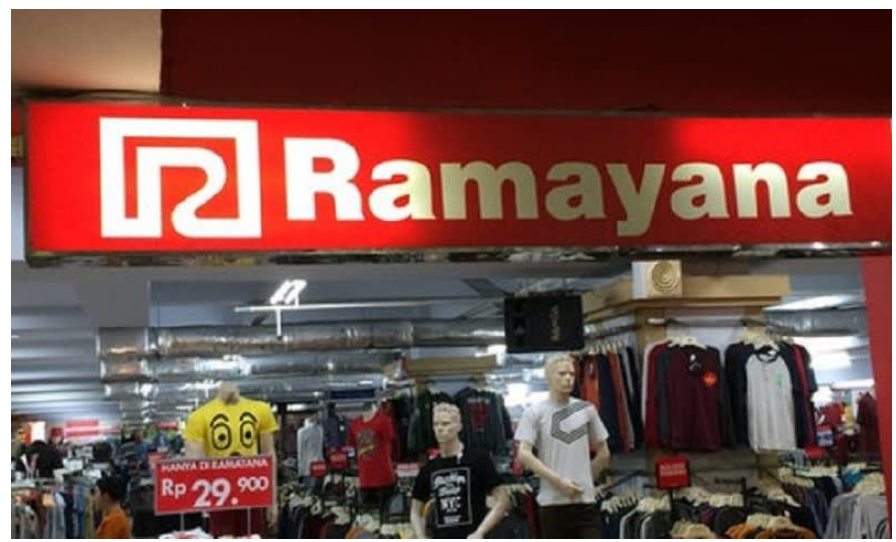

Gambar 4: Gerai Ramayana

Toko serba ada yang sudah cukup lama berdiri milik PT Ramayana Lestari Sentosa Tbk ini telah tutup sebanyak 8 gerai di berbagai daerah karena merugi. Gerai Ramayana yang ditutup itu antara lain 2 gerai yang ada di Surabaya, 1 di Gresik, 1 di Banjarmasin, 1 di Bulukumba, 1 di Bogor, 1 di Pontianak, dan 1 gerai Ramayana di Sabang

\section{Hero Supermarket}

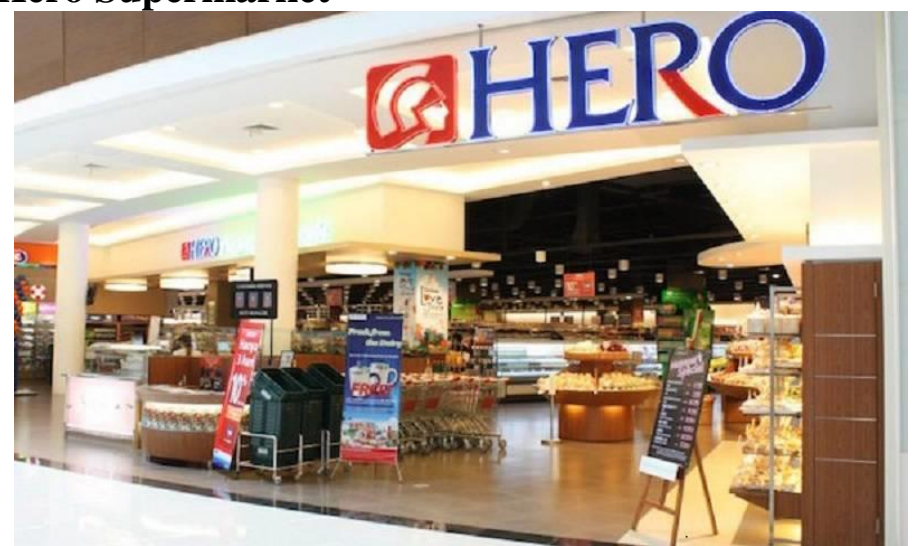

Gambar 5: Gerai Hero

Bukan hanya riwayat toserba, namun peritel di Indonesia seperti PT Hero Supermarket Tbk, juga mengalami nasib yang sama. Hero telah menutup 74 gerai dari semua jenis supermarket dan hypermarket di tahun 2015 lalu. Diakui, penutupan gerai ritel yang menyediakan kebutuhan sehari-hari ini salah satunya karena terdampak pelemahan ekonomi.

\section{Hypermarket}




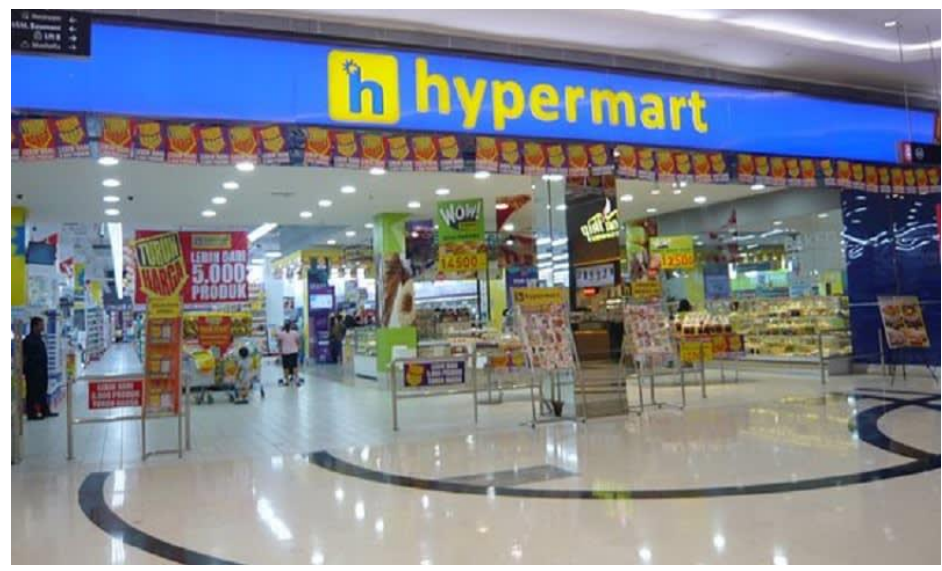

Gambar 6: Gerai Hypermart

Gerai ritel yang menjual berbagai macam kebutuhan sehari-hari ini terpaksa tidak bisa dioperasikan semua. PT Matahari Putra Prima Tbk tahun ini telah menutup 2 gerai Hypermart, salah satunya lantaran mengalami penurunan penjualan. Selain itu, diungkapkan juga karena biaya operasional yang tidak mendukung untuk tetap efisien.

\section{Sevel (seven eleven)}

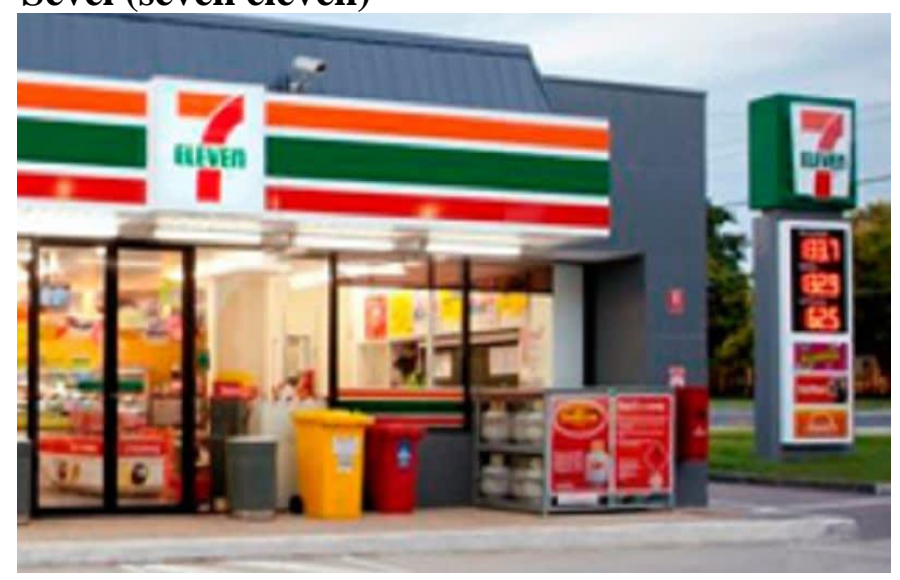

Gambar 7: Gerai Sevel

Bukan hanya supermarket, namun ritel jenis convenient store seperti Sevel (7-Eleven) pun mengalami nasib yang sama. Bukan hanya 1-2 gerai atau beberapa gerai saja yang tidak mampu bertahan, namun Manajemen PT Modern Internasional Tbk nyatanya memilih menutup seluruh outlet 7-Eleven.

Gerai yang biasa disebut sebagai 'Kafenya' anak muda dan gaul ini tak mampu mempertahankan eksistensinya. Bukan apa-apa, masalah biaya operasional yang tak sesuai dengan pendapatan telah menjerat langkah Sevel ini untuk bisa terus eksis. 


\subsection{Pembatasan Masalah}

Banyak faktor yang menyebabkan penjualan secara ritel mengalami kemunduran bila dibandingkan tahun-tahun sebelumnya. Dalam penulisan jurnal ini, penulis membatasi dan memfokuskan pada pengaruh penjualan secara online terhadap penjualan secara ritel.

\subsection{Tujuan Penelitian}

Tujuan yang ingin dicapai dari penelitian ini adalah sebagai berikut:

1. Untuk mengetahui hubungan antara penyediaan jasa penjualan secara online dengan penurunan penjualan secara ritel.

2. Untuk mengetahui hubungan antara penyediaan jasa penjualan secara online dengan pertumbuhan ekonomi Indonesia.

3. Untuk mengetahui dampak dari penjualan secara online terhadap perusahaan ritel dan bagaimana mereka mengantisipasi terhadap perubahan pola pembelian konsumen

\section{LANDASAN TEORI}

Banyak pihak beranggapan bahwa turunnya penjualan dikarenakan lesunya ekonomi Indonesia saat ini. Ternyata bahwa turunnya penjualan disebabkan beberapa hal, salah satunya adalah terjadinya suatu pergeseran penjualan dari penjualan tradisional menjadi penjualan yang berbasiskan online.

Disisi lain ternyata terjadi perubahan ke arah baik yaitu penjualan secara online. Dimana dari tahun ke tahun terjadi peningkatan signifikan, banyak faktor yang menyebabkan penjualan secara online terjadi peningkatan yang cukup bagus dari tahun ke tahun antara lain disebabkan adanya harga perangkat akses ke internet semakin murah seperti perangkat handphone yang memudahkan seseorang dapat mengakses dunia maya. Faktor lainnya adalah generasi sekarang yang semakin akrab dengan dunia teknologi, dan faktor lainnya adalah dari sisi penjual yang juga mengikuti perkembangan zaman yang mendorong mereka melakukan perubahan dari penjualan secara tradisional menjadi penjualan secara online.

Mengetahui perubahan perilaku dari pembeli membuat para penjual melakukan adaptasi terhadap perubahan ini. Para pelaku bisnis dipaksa untuk mengikuti perubahan perilaku konsumen ini dengan melakukan penjualan secara online di dunia maya. Beberapa perusahaan melakukan penjualan secara online dengan menjual produk barangnya di tempat situs perdagangan yang cukup terkenal seperti yang telah disebutkan di atas. Ada juga beberapa pelaku bisnis yang memiliki infrastruktur yang cukup kuat dengan menjual barang dagangannya di web yang mereka miliki sendiri. 
Perubahan metode penjualan yang membuat para perilaku bisnis mendifinisikan ulang bagaimana mereka menjual produknya ke konsumen. Banyak faktor yang menyebabkan perubahan bisnis proses metode penjualan ini. Namun pada kesempatan ini Penulis memfokuskan pada beberapa variabel yang menyebabkan terjadinya perubahan bisnis perusahaan dari tradisional menjadi online yaitu antara lain:

- Peningkatan pembelian secara online.

- Melambatnya pertumbuhan penjualan secara retail

- Hubungan peningkatan penjualan terhadap pertumbuhan ekonomi Indonesia

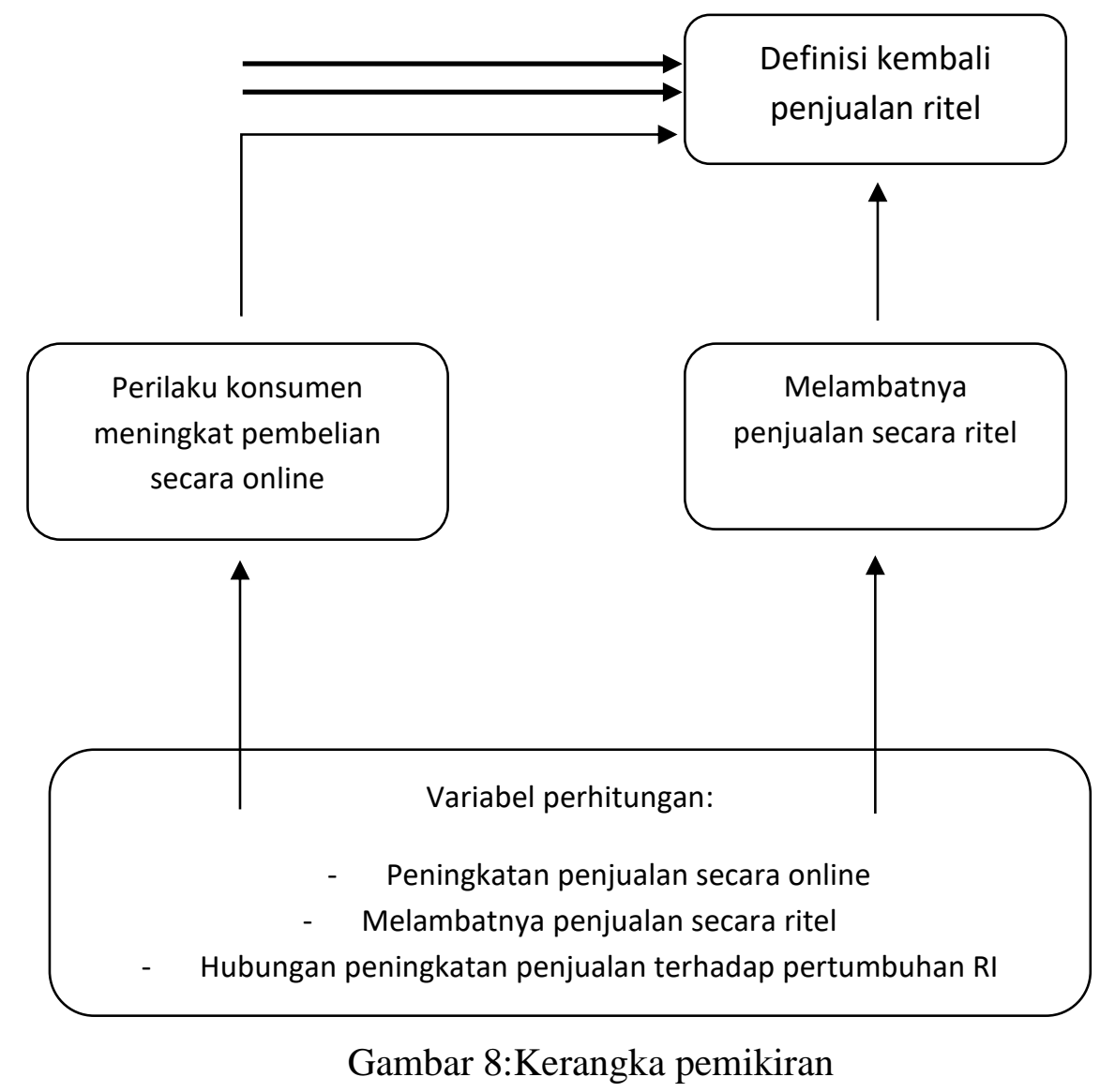

\section{METODE PENELITIAN}

\subsection{Metode penelitian}

Terjadi perubahan perilaku konsumen dari pembelian secara tradisional atau ritel menjadi pembelian secara online. Para perilaku bisnis merespon perubahan gaya perilaku konsumen ini dengan melakukan penjualan secara online dan sebagian dari mereka tetap mempertahankan penjualan secara ritel juga. 
Dalam melakukan penelitian studi kasus ini prosedur atau urutan Metode penelitian ini adalah jenis penelitian; pengumpulan data, teknik pengolahan data, teknik analisis data.

\subsection{Jenis penelitian}

Penelitian ini termasuk dalam jenis penelitian deskriptif. Penelitian ini melukiskan kejadian perubahan perilaku konsumen dari pembelian secara ritel ke arah online. Dengan perubahan perilaku ini membuat perusahaan meningkatkan penjualan dengan menambah metode penjualan dari penjualan secara ritel ditambah dengan penjualan secara online. Perubahan gaya konsumen ini membuat melambatnya laju penjualan secara ritel tetapi secara nasional tetap mempertahankan tren positif pertumbuhan ekonomi Indonesia secara keseluruhan.

\subsection{Teknik pengumpulan data}

Data yang digunakan dalam jurnal ini berasal dari pihak kedua (data sekunder) atau bukan data yang dihimpun langsung oleh peneliti ke sumber data. Jenis data sebagian besar berupa data-data kuantitatif dari laporan penjualan online dan ritel serta pertumbuhan ekonomi Indonesia. Sedangkan data kualitatif diperoleh dari penjelasan dan berita-berita tentang perilaku konsumen terhadap penjualan secara online maupun tradisional.

Metode pengumpulan data yang digunakan penulis adalah dengan cara dokumentasi yaitu mengumpulkan data-data yang relevan baik dari internet, makalah, maupun media koran dan lain-lain.

\subsection{Jangka waktu}

Laporan penjualan yang digunakan dalam penelitian ini adalah laporan penjualan dari tahun 2013 - 2017. Perhitungan dari tahun 2013 hingga tahun 2017 agar dapat menciptakan gambaran penjualan yang lebih luas agar dapat mendapatkan gambaran lebih akurat..

\subsection{Teknik pengolahan data}

Yang dilakukan dalam pengolahan data pertama adalah dikumpulkan terlebih dulu semua data-data yang berhubungan penjualan secara online maupun secara tradisional serta pertumbuhan ekonomi Indonesia dari berbagai sumber. Lalu dilakukan pemilihan yang data benar-benar berhubungan dengan penjualan baik secara online maupun tradisional, dan dibuat kelompok atau diklasifikasikan untuk mempermudah penelitian.

\subsection{Teknik analisis data}


Teknik analisis data untuk mengukur peningkatan penjualan secara online dan secara tradisional oleh para perilaku bisnis Indonesia.

Pertama, anlisis peningkatan penjualan secara ritel, serta perbandingan dengan pertumbuhan ekonomi Indonesia.

Tabel 1: Data penjualan online, penjualan ritel dan pertumbuhan Ekonomi Indonesia 2013-2017

\begin{tabular}{|c|l|l|l|l|}
\hline No & Tahun & Penj online & Penj ritel & $\begin{array}{l}\text { Pertumbuhan } \\
\text { Ekonomi Indonesia }\end{array}$ \\
\hline 1 & 2017 & $108 \mathrm{~T}$ & $219 \mathrm{~T}$ & $5.07 \%$ \\
\hline 2 & 2016 & $70 \mathrm{~T}$ & $199 \mathrm{~T}$ & $5.02 \%$ \\
\hline 3 & 2015 & $42 \mathrm{~T}$ & $181 \mathrm{~T}$ & $4.79 \%$ \\
\hline 4 & 2014 & $25 \mathrm{~T}$ & $165 \mathrm{~T}$ & $5.02 \%$ \\
\hline 5 & 2013 & $17 \mathrm{~T}$ & $150 \mathrm{~T}$ & $5.78 \%$ \\
\hline
\end{tabular}

Sumber: data diolah dari berbagai sumber.

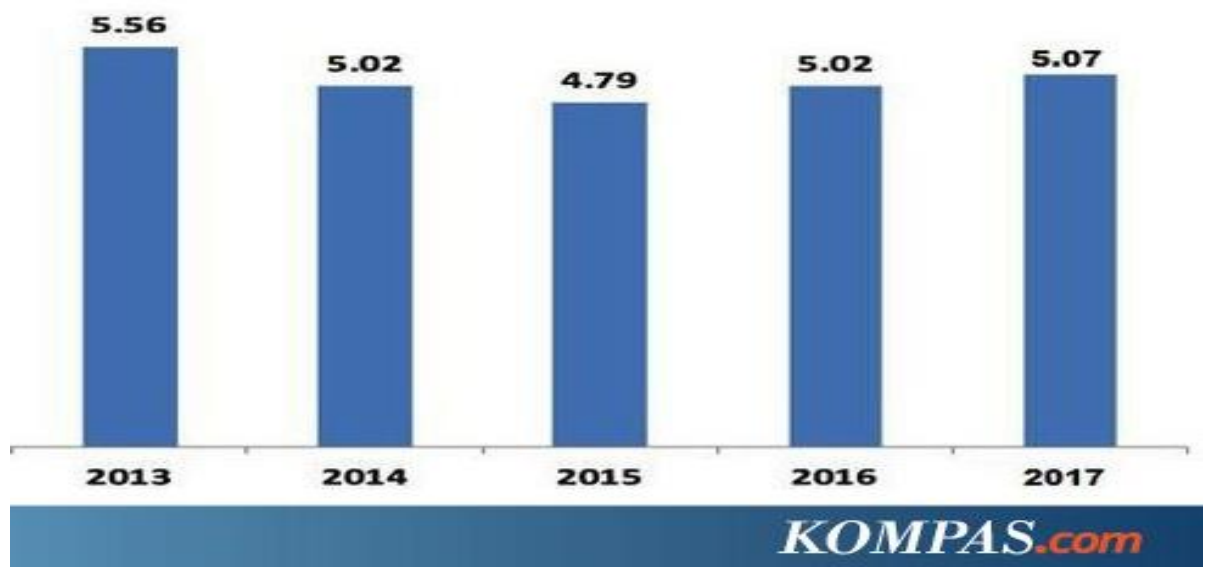

Gambar 9: pertumbuhan ekonomi Indonesia

Kedua, analisis peningkatan penjualan secara online serta perbandingan dengan pertumbuhan ekonomi Indonesia. Ketiga, analisa hubungan penjualan ritel terhadap pertumbuhan ekonomi Indonesia. Keempat, analisa hubungan penjualan online terhadap pertumbuhan ekonomi Indonesia. Kelima komperasi penjualan online dengan penjualan secara ritel. 


\section{TEMUAN-TEMUAN}

Berdasarkan hasil penelitian dan pembahasan tentang penjualan secara online yang meliputi beberapa sub bab yaitu: peningkatan penjualan secara online, hubungan penjualan online terhadap pertumbuhan ekonomi Indonesia yang lebih baik, serta data penjualan online yang mengalami kenaikan signifikan dibandingkan dengan penjualan secara ritel.

\subsection{Perhitungan peningkatan penjualan ritel}

Walaupun pertumbuhan ekonomi Indonesia mengalami turun naik dari tahun 2013 hingga tahun 2017 tetapi pertumbuhan ritel Indonesia tetap mengalami kenaikan. Pada saat pertumbuhan ekonomi Indonesia mengalami kenaikan yang terendah pada tahun 2015, kenaikan ritel juga mengalami penurunan pertumbuhan penjualan di bidang ritel.

Tabel 2: data penjualan ritel vs pertumbuhan ekonomi RI

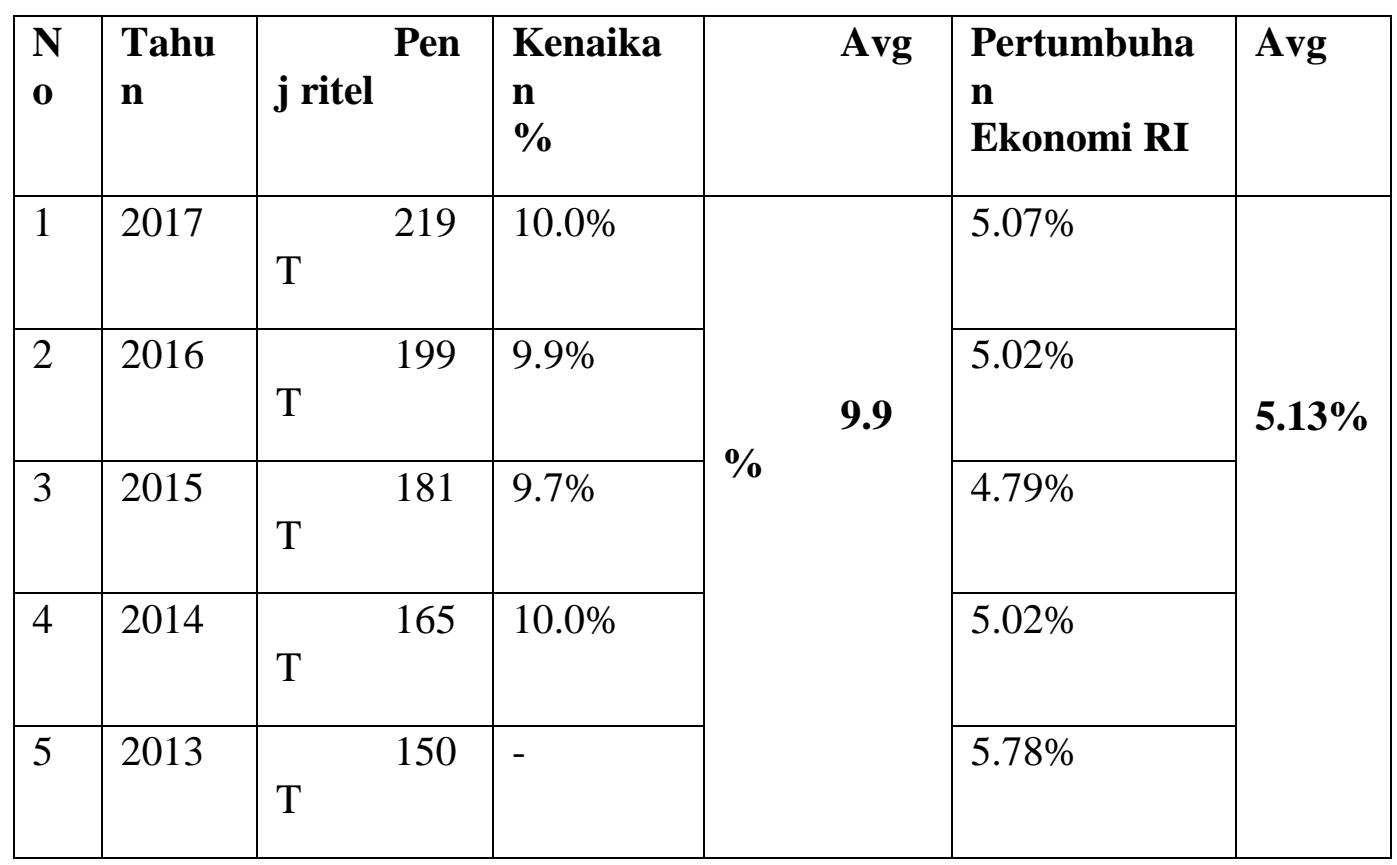

Sumber: data diolah dari Aprindo

\subsection{Perhitungan peningkatan penjualan secara online}

Walaupun pertumbuhan ekonomi mengalami turun dan naik dari periode tahun 2013 sampai tahun 2017, namun penjualan secara online tetap mengalami konsistensi yang mengalami kenaikan secara fantastis, pada saat pertumbuhan ekonomi mengalami penurunan pada tahun 2015, kenaikan penjualan online sebesar $68 \%$. 
Beberapa faktor pendukung penyebab pertumbuhan secara online mengalami peningkatan yang secara signifikan antara lain:

- Perangkat keras alat penunjang alat komunikasi yang semakin murah.

- Biaya penggunaan alat komunikasi yang mengalami penurunan dibandingkan pada era pertama kali alat komunikasi seperti handphone ini dikeluarkan.

- Budaya masyarakat dunia termasuk Indonesia yang semakin dekat dengan teknologi yang lebih baik termasuk terhadap handhpone.

- Harga yang ditawarkan di dunia maya jauh lebih murah dibandingkan dengan toko ritel, karena penjualan ritel yang minim dengan biaya seperti biaya sewa, biaya tenaga kerja dll.

- Spesifikasi barang yang jauh lebih lengkap yang disajikan dan juga pilihan terhadap barang yang kita inginkan jauh lebih banyak.

- Transaksi yang jauh lebih aman, dibandingkan pertama kali era penjualan secara online ini dimulai. Dan beberapa pelaku kejahatan dalam dunia maya ini ditangkap pihak berwajib yang akhirnya menciptakan rasa aman untuk bertransaksi.

Tabel 3: Data penjualan online

\begin{tabular}{|l|r|l|l|l|}
\hline No & \multicolumn{1}{|l|}{ Tahun } & Penj online & $\begin{array}{l}\text { Kenaikan } \\
\%\end{array}$ & \multirow{2}{*}{ Avg } \\
\hline 1 & 2017 & $108 \mathrm{~T}$ & $54.29 \%$ & \\
\cline { 1 - 4 } & 2016 & $70 \mathrm{~T}$ & $66.67 \%$ & \multirow{2}{*}{$\mathbf{5 9 . 0 \%}$} \\
\hline 3 & 2015 & $42 \mathrm{~T}$ & $68.0 \%$ & \\
\hline 4 & 2014 & $25 \mathrm{~T}$ & $47.05 \%$ & \\
\hline 5 & 2013 & $17 \mathrm{~T}$ & - & \\
\hline
\end{tabular}

Sumber data diolah dari Aprindo

\subsubsection{Pengharuh penjualan ritel terhadap Pertumbuhan ekonomi Indonesia}

Pada perhitungan yang ini menggunakan analisis korelasi yaitu metode statistic yang digunakan untuk mengukur besarnya hubungan linear antara dua variable atau lebih. Tujuannya adalah untuk mengetahui apakah diantara dua variable terdapat hubungan baik atau tidak, dan jika ada hubungan bagaimanakah arah hubungan dan sebesar besar hubungan tersebut.

Dimana hasil dari koefisien korelasi ini antara -1 sampai dengan 1. Bila hasilnya negatif berarti hubungan tersebut berlawanan dan bila angka 1 berarti hubungannya searah. Dan bila angkanya mendekati angka 0 berarti hubungannya semakin lemah, dan bila mendekati angka 1 atau -1 berarti hubungan semakin kuat searah atau berlawanan. 


$$
R=\frac{n \Sigma X Y-\Sigma X \Sigma Y}{\sqrt{n \Sigma x x^{2}-(\Sigma x)^{2}} \sqrt{n \Sigma y^{2}-(\Sigma Y)^{2}}}
$$

Dimana:

$\mathrm{R}=$ koefisien korelasi

$\mathrm{N}=$ jumlah sample yang diambil

$\mathrm{X}=$ variable independent (Penjualan ritel/online)

$\mathrm{Y}=$ variable dependent (pertumbuhan RI)

Berikut ini adalah tabel perhitungan koefisien korelasi antara penjualan secara ritel terhadap pertumbuhan ekonomi Indonesia.

Tabel 4: perhitungan koefisien korelasi

\begin{tabular}{|c|c|c|c|c|c|c|}
\hline No & Tahun & $\mathbf{x}$ & $y$ & $x 2$ & y2 & xy \\
\hline 1 & 2017 & 219 & $5,07 \%$ & 47961 & $0,26 \%$ & 11,1033 \\
\hline 2 & 2016 & 199 & $5,02 \%$ & 39601 & $0,25 \%$ & 9,9898 \\
\hline 3 & 2015 & 181 & $4,79 \%$ & 32761 & $0,23 \%$ & 8,6699 \\
\hline 4 & 2014 & 165 & $5,02 \%$ & 27225 & $0,25 \%$ & 8,283 \\
\hline 5 & 2013 & 150 & $5,78 \%$ & 22500 & $0,33 \%$ & 8,67 \\
\hline \multicolumn{2}{|c|}{ Total } & 914 & $25,68 \%$ & 170048 & $1,32 \%$ & 46,716 \\
\hline
\end{tabular}

Sumber data diolah dari Aprindo

\section{Dan nilai $\mathrm{r}=0.212 \%$}

Artinya hubungan penjualan secara ritel dengan pertumbuhan ekonomi Indonesia searah dan memiliki hubungan sebesar $0.212 \%$

\subsubsection{Pengharuh penjualan online terhadap Pertumbuhan ekonomi Indonesia}

Pada perhitungan hubungan penjualan secara ritel dengan pertumbuhan ekonomi Indonesia sebesar 0,212\%. Lalu berikut ini adalah perhitungan penjualan secara online dengan pertumbuhan ekonomi Indonesia sebagai berikut:

Tabel 5: Perhitungan koefisien korelasi 


\begin{tabular}{|c|c|c|c|c|c|c|}
\hline No & Tahun & $\mathbf{x}$ & $y$ & $\times 2$ & y2 & xy \\
\hline 1 & 2017 & 108 & $5,07 \%$ & 11664 & $0,26 \%$ & 5,4756 \\
\hline 2 & 2016 & 70 & $5,02 \%$ & 4900 & $0,25 \%$ & 3,514 \\
\hline 3 & 2015 & 42 & $4,79 \%$ & 1764 & $0,23 \%$ & 2,0118 \\
\hline 4 & 2014 & 25 & $5,02 \%$ & 625 & $0,25 \%$ & 1,255 \\
\hline 5 & 2013 & 17 & $5,78 \%$ & 289 & $0,33 \%$ & 0,9826 \\
\hline \multicolumn{2}{|c|}{ Total } & 262 & $25,68 \%$ & 19242 & $1,32 \%$ & 13,239 \\
\hline
\end{tabular}

Sumber data diolah dari Aprindo

Dari hasil perhitungan dengan rumus koefisien korelasi menghasilkan angka di $0,223 \%$ yang Artinya terjadi hubungan yang searah dan memiliki hubungan sebesar $0,223 \%$ atau memiliki hubungan yang lebih besar sebesar $0,011 \%$.

Keduanya baik penjualan secara online maupun secara ritel, memiliki hubungan searah dengan pertumbuhan ekonomi Indonesia. Untuk penjualan secara online memiliki hubungan yang lebih kuat dibandingkan dengan penjualan secara ritel. Ke depan dimana penjualan secara online mungkin akan semakin besar pengaruhnya terhadap pertumbuhan ekonomi Indonesia karena seperti data sebelumnya penjualan secara online mengalami kenaikan persentase rata-rata $59 \%$ untuk rentang tahun 2013-2017.

\section{Komperasi data penjualan secara online vs secara penjualan ritel}

Komperasi perbandingan penjualan secara online dengan penjualan secara online dari tahun 2013 sampai dengan tahun 2017 sebagai berikut:

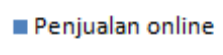

- Penjualan ritel
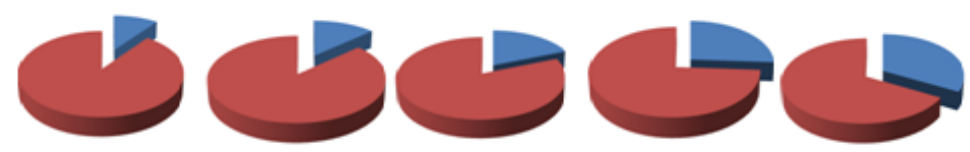

\begin{tabular}{|c|c|c|c|c|c|}
\hline \multicolumn{1}{|c|}{ Tahun } & \multicolumn{1}{|c|}{$\mathbf{2 0 1 3}$} & $\mathbf{2 0 1 4}$ & $\mathbf{2 0 1 5}$ & $\mathbf{2 0 1 6}$ & \multicolumn{1}{c|}{$\mathbf{2 0 1 7}$} \\
\hline Penjualan online & $17 \mathrm{~T}(10.2 \%)$ & $25 \mathrm{~T}(13.2 \%)$ & $45 \mathrm{~T}(18.8 \%)$ & $70 \mathrm{~T}(26 \%)$ & $108 \mathrm{~T}(33 \%)$ \\
\hdashline Penjualan ritel & $150 \mathrm{~T}(89.8 \%)$ & $165 \mathrm{~T}(86.8 \%)$ & $181 \mathrm{~T}(81.2 \%)$ & $199 \mathrm{~T}(74 \%)$ & $219 \mathrm{~T}(67 \%)$ \\
\hline
\end{tabular}

Gambar 10: Data penjualan online vs data penjualan ritel

\section{SIMPULAN dan SARAN}

\subsection{Simpulan}


Penjualan secara online secara signifikan mengalami perkembangan yang pesat beberapa tahun belakangan ini. Banyak pihak menyadari hal ini, dan beberapa pihak penjual telah beradaptasi dengan perubahan tren penjualan dan beberapa masih mengikuti pola penjualan secara ritel.

Pola penjualan secara online membawa banyak kemudahan serta harga yang sangat kompetitif yang tentu akhirnya akan menguntungkan para konsumen dan para penjual via online itu sendiri.

Beberapa perusahaan atau para pengusaha belum menjalankan usahanya secara online. Karena perpindahan konsumen dari manual penjualan secara ritel ke online, yang membuat mereka mengalami performa usaha yang kondisi sulit bahkan akhirnya tutup. Namun ada beberapa perusahaan walaupun tidak melakukan penjualan secara online namun bertahan, mayoritas karena pola penjualan yang lebih bagus bila dilakukan secara ritel, contohnya pedagang pasar yang menjual barang dagang mereka hasil bumi yang sangat murah dan langsung dijual ke langsung pembeli.

\subsection{Saran}

Dari hasil beberapa temuan dari uraian informasi di atas dan penulis menyarankan beberapa saran sebagai berikut:

- Penjualan secara online dari tahun ke tahun mengalami volume yang naik cukup signifikan. Banyak para konsumen yang dulunya melakukan pembelian secara manual namun sekarang banyak para konsumen mulai melakukan pembelian secara online. Ini merupakan suatu peluang bagi para pelaku usaha untuk melebarkan penjualan mereka secara online.

- Jangkauan penjualan secara online ini tidak terbatas wilayah, bahkan dapat melakukan penjualan atau pembelian lintas negara. Hal ini berbeda dengan penjualan secara ritel yang hanya melakukan penjualan secara lokal. Jangkauan yang luas ini merupakan suatu peluang bagi pelaku usaha.

- Penjualan secara online sekarang biaya investasinya relatif terjangkau bagi pelaku pengusaha, namun return manfaat dari investasi ini sangat besar bagi perusahaan. Dengan demikian sangat disarankan untuk mengimplementasikan penjualan secara online, kecuali bila usahanya modelnya lebih baik secara ritel daripada online.

- Beberapa perusahaan akan mengalami kurangnya daya saing bila para competitor sudah melakukan penjualan secara online. Ancaman harus diperhatikan serius oleh para pelaku usaha, bila usahanya ingin tetap bertahan dan berkembang. 


\section{DAFTAR PUSTAKA}

Ahmad Shukri Yahaya, Buku Rumus Statistik, Prentice Hall 2002

Dhimas Ari Mahardhika Putra, Pengaruh Promosi terhadap Peningkatan Penjualan pada distribusi Outlet di Bekasi,http://mahardhikaputra31.blogspot.com/2011/01/pengaruhpromosi-terhadap-peningkatan.html

Anastasia, Diana. (2004). Mengenal e-Business. Andi, Yogyakarta. 